\title{
Saving Money at the Grocery Store ${ }^{1}$
}

\section{Glenda L. Warren²}

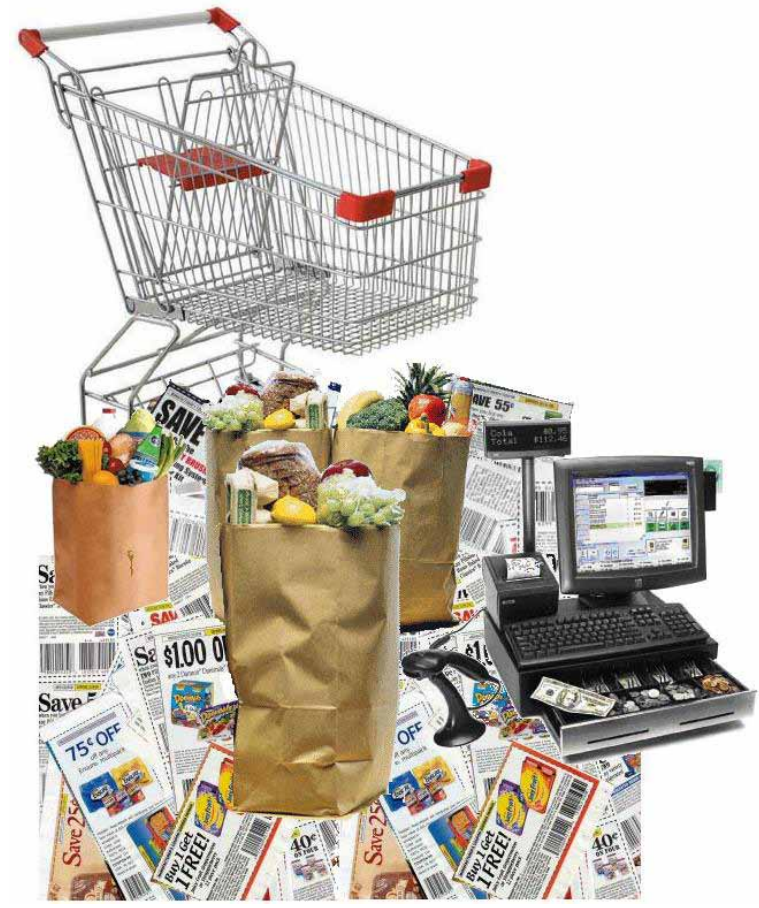

Figure 1. A little really can go a long way when you plan ahead. Credits: Image by Mike Licht, NotionsCapital.com. CC BY 2.0. Source: http://flic.kr/p/5xGtc3.

\section{A good shopping list is your number one tool to help} stretch food dollars and save money at the grocery store. You must plan ahead to have a good list, and plan to stick to the list.

\section{A good list is based on:}

- Your budget - Know how much you can spend for food.
- Your meal plans - What will your family eat between food shopping trips?

- Nutritional needs of your family.

3. You must plan ahead. List things as they run low, so you won't have to make extra trips to the store. Extra trips can ruin your food budget due to all the temptations in the store.

4. Also, plan ahead to have everything needed for meals and snacks before the next planned trip to buy groceries.

5. Your plans should also include enough foods from each food group to provide healthy eating for you and your family.

6. Plan ahead and eat before you go food shopping. Never go grocery shopping when you are hungry. If you are hungry in the grocery store, you are likely to buy way too much food. Hungry shoppers buy too much and usually make poor food choices.

7. If possible, shop alone. If you must take children with you or even another adult, be sure that they have eaten before you go shopping. Also, make them your shopping partners by allowing them to make some selections within preset limits. For example, if apples are on your list, and the price is about the same for the amount that you plan to buy, they could decide if you get red delicious apples or golden delicious apples.

1. This document is FCS8851, one of a series of the Family Youth and Community Sciences Department, Florida Cooperative Extension Service, Institute of Food and Agricultural Sciences, University of Florida. Original publication date December 19, 2008. Reviewed with minor revision November 2011 by Karla P. Shelnutt, assistant professor. Visit the EDIS website at http://edis.ifas.ufl.edu.

2. Glenda L. Warren, M.S., R.D., CFCS, former associate professor, Extension nutritionist, EFNEP, Department of Family, Youth and Community Sciences, Florida Cooperative Extension Service, Institute of Food and Agricultural Sciences, University of Florida, Gainesville 32611. 
8. Be sure your shopping partners can help stay within the budget. Teach them to use these skills to compare prices:

- Read store ads

- Use unit prices

- Compare store brands with national brands

- Use coupons

- Read food labels

9. Always read the grocery ads. Many times just what you need will be on sale, or a substitute item is on sale. If you can buy and use the extra before it spoils, this would be a good time to stock up.

10. Use unit prices. The unit price is the price for one "measure" of the item. For example it may be the price per pound or the price per ounce. Many stores will have the unit price labels on the shelf just below the item. Make careful comparisons. You will find that sometimes, the larger container will have the best price per unit, and sometimes the smaller container will have the best price. If the larger size has the best price, then buy the largest size if you can, store and use it before it goes to waste.

11. Compare store brands or no-name brands with the well-known national brands. The store brands or noname brands are almost always cheaper than the name brands.

12. Use coupons if it really helps save money for something that you need to buy. Even with a coupon, sometimes the national brand is still more expensive than the store brand.

13. When comparing some food items, you need to compare the cost per serving or the cost per meal. For example, some meats have a lot of bones. So even though it may be the lowest cost per pound, it is not the best buy because so much of it cannot be eaten.

14. Use the food label especially the nutrition facts panel. The food label makes it easier to compare different foods and make healthier food choices, including how to:

- Check the serving size and number of servings

- Compare the number of calories per serving

- Determine if a food is high or low in a nutrient
15. Always consider food safety when shopping for food. Buy the refrigerated and frozen items last so that they can keep at a safe temperature until you reach home. If the weather is very hot or if you cannot go home immediately, take a cooler with ice in your car, so foods can be kept at a safe temperature.

16. Place any meat that may drip away from other foods to avoid cross contamination. In other words keep foods separate for safety.

17. It pays to know your prices so you can tell whether or not you are getting a good deal. Keep track of the cost of the items that you usually buy. You can jot down the price of things while in the store, or you can review your receipts and jot the prices in your planning "notebook" at home. Maybe one of the children can help.

18. Watch out for those items that are known as impulse items. Stick to your shopping list and limit or avoid those extras like sodas, alcohol, sweets, and chips. Such items are usually high in cost, high in calories, and low in nutritional value.

19. Be careful when checking out. Many items are placed to get your money one more time before you check out. Such tempting nonessentials are there like candy, gum, magazines, and so forth. Candy is often placed at the eye level of children riding in the grocery cart. Some stores have a "candy free" check out lane. Take advantage of such lanes. If one is not there, perhaps you can request it.

20. Finally, be sure to pay extra attention at the checkout. Watch the price scanners and check receipts for price errors. Be sure you have handed the checker any coupons or discounts that you are entitled to.

21. Always plan ahead and take advantage of things that you can do to save money at the grocery store. 